\title{
The English-Majored Sophomores' Self-Perception of Autonomous Language Learning
}

\author{
Truong Minh Hoa ${ }^{1}$, Nguyen Thi Thu Thuy ${ }^{2} \&$ Luu Thi Huyen Tran ${ }^{3}$ \\ ${ }^{1}$ School of Foreign Languages, Nguyen Tat Thanh University, Ho Chi Minh City, Vietnam \\ ${ }^{2}$ School of English Language, Linh Trung High School, Ho Chi Minh City, Vietnam \\ ${ }^{3}$ School of English Language, Dien Bien Secondary School, Ho Chi Minh City, Vietnam \\ Correspondence: Truong Minh Hoa, Nguyen Tat Thanh University, Ho Chi Minh City, Vietnam.
}

Received: October 10, 2019 Accepted: November 17, 2019 Online Published: November 20, 2019

doi: 10.5539/elt.v12n12p119 URL: https://doi.org/10.5539/elt.v12n12p119

\begin{abstract}
Learner autonomy, which places the great emphasis on the learners' independent roles and responsibilities in their learning process, has become the main concern of language education for over three past decades. It is important to investigate the language learners' self-perception of their autonomous responsibilities, their possession of autonomous abilities, and their enactment of autonomous in-class and out-of-class behaviors. Thereby, the current study adopted features of a mixed-methods research design to examine these autonomous dimensions as perceived by university learners. A sample of eighty English-majored sophomores from Hung Vuong University, Vietnam was recruited for the current study. Their self-perception of autonomous language learning was elicited through two instruments of a thirty-two-item questionnaire and a nine-question semi-structured interview. Then the questionnaire data were quantitatively analyzed and the interview data were qualitatively analyzed. The results of this study indicated that the majority of the participants positively acknowledged the importance of learner autonomy, discerned their gained autonomous learning responsibilities, recognized their existing autonomous abilities, and unveiled some enacted autonomous learning behaviors inside and outside class.
\end{abstract}

Keywords: autonomous language learning, English-majored, self-perception, sophomores

\section{Introduction}

Deeply governed by the Confucian premise, teaching and learning English in some Asian parts, including Vietnam, has been traditionally enacted by the core mission of the teachers is to transmit the knowledge to their students rather than guiding students to become independent in their learning (Trinh, 2005). In such traditional classes, learners are inclined to be very passive and heavily dependent upon their teachers for learning, receiving knowledge in lieu of constructing it (Nguyen, 2014). Yet, in many Asian countries these days, learners are no longer passive recipients but much expect to be more active and autonomous agents, which was eventually spotlighted by Littlewood (2000), Dang (2012), Duong (2015), and Nguyen (2019).

In academia, learner autonomy has received great concern from numerous theorists around the world (e.g. Holec, 1981; Wenden, 1991; Littlewood, 1996; Benson, 2007; Benson, 2011) for more than three decades (Borg \& Al-Busaidi, 2012). The burgeoning of learner autonomy is considered as one of the most prominent pedagogical goals and as "one of the key competences for lifelong learning" (Vázquez, 2014, p. 59). It is inferred that to be good inhabitants in the knowledge-based society of the $21^{\text {st }}$ century, learners need to extensively rely on their own inquiries. They need to develop their own capacities such as creativity, critical thinking, social responsibility, decision-making and problem-solving skills, etc. as language learning process is purposely framed through learners' own reflection on how they learn and manage their learning strategies (Al-Asmari, 2013). In brief, success of a foreign language acquisition relies on a great extent on learner autonomy both to take initiative in the classroom and persist in their learning path outside classroom (Brown, 2007).

Besides, autonomous learning shifts from teacher-centered environment to student-centered one (Voller, 1997) where learners are responsible for formulating goal, planning their learning process, identifying resources of learning, choosing and utilizing appropriate strategies to learn, and evaluating their learning process (Holec, 1981). However, this is a gradual, cumulative and collaborative process (Camilleri, 2000) which also 
necessitates teachers' rejuvenated roles. It means that teachers should change their role from the dominant source of information to counselor, tutor, manager and active participants of learning resources to facilitate their learners' autonomous learning (Nguyen, 2014). As such facilitating roles, the teacher can help learners to plan and carry out their own learning, such as setting objectives, selecting materials, evaluating their learning, etc. (Duong, 2015). On the other hand, to become effective autonomous learners, learners should "reflect on their own learning, take initiative towards their own learning, set goals and evaluate their own progress" (Riihimäki, 2013, p. 21). In other words, autonomous learners need to self-plan, self-control, self-regulate and self-evaluate their own learning process without being reminded by their teachers or waiting for the teachers' instruction.

Any definition of learner autonomy is likely to be subjective (Han, 2014). Put it simply, there are some variations in defining learner autonomy concept under diverse angles (e.g. technical, psychological, socio-cultural, or political-critical perspectives) from numerous authors in varied contexts. The initiator Holec (1981) defines this concept with some characteristics; in specific, learner autonomy refers to the focal point on learners themselves, in which learners' capacity is accumulated through a systematic and intended learning process, involving their psychology (e.g. attitudes or perceptions) and actions. In addition, Littlewood (1999) conceptualizes this term that it embodies learners' willingness to be responsible for their own learning. In similar fashion, Sinclair (2000) also tallies that "learner autonomy is a construct of capacity, [consisting] of learners' willingness to be responsible for their own learning" (p. 5); nevertheless, this author adds that it can occur both inside and outside the classroom. In a nutshell, based on these definitions, the researcher focused on three dimensions of learner autonomy, inclusive of autonomous responsibilities, abilities, and inside and outside behaviors.

The aim of the current paper was to investigate the scope of autonomous language learning as self-perceived by the English-majored sophomores at Hung Vuong University, Vietnam. This paper, accordingly, formulated the following question: How do the English-majored sophomores self-perceive their autonomous language learning at Hung Vuong University, Vietnam?

\section{Method}

\subsection{Participants}

The study recruited the participation of 80 English-majored sophomores at Hung Vuong University, Vietnam thanks to convenience sampling technique. Among these participants, there were 61 females $(76.25 \%)$ and 19 males $(23.75 \%)$. Their age range varied from 19 to 22 years old. Their English proficiency was expected to reach B1 level in the Common European Framework of Reference for Languages (CEFR).

\subsection{Research Design}

This study was grounded in a mixed-methods design to collect sufficient data for the research question. In specific, the study used quantitative data from responses of 80 questionnaire copies and then qualitative data from eight semi-structured interviews to add further information to the gathered quantitative data. By reason, the amalgamation of both qualitative and quantitative data can help "better understand the research problem and question than either method by itself"' (Creswell, 2012, p. 535).

\subsection{Research Instruments}

The researcher decided to utilize a questionnaire which is known to be one of the easiest methods to manage, even with large numbers of subjects (Dörnyei, 2010) and one of the most useful tools to exploit the subjects' attitudes, beliefs and perceptions (Koshy, 2005). The 32-item questionnaire consisted of four distinct sections. The first section was associated with the participants' overall self-perception of the importance of learner autonomy (Items I1-4), followed by the second section which addressed the sample's self-perception of their autonomous responsibilities (Items R1-10), and the third section which focused on the participants' self-perception of their autonomous abilities (Items A1-7). The last section was pertinent to the respondents' self-perception of their autonomous inside behaviors (Items IB1-3) and outside behaviors (Items OB1-8). These items were rated on a five-point Likert-scale, including $1=$ totally disagree, $2=$ disagree, $3=$ uncertain, $4=$ agree, and $5=$ totally agree. The questionnaire was reliable as proven by its internal consistency indexes. As evidenced in Table 1 below, the Cronbach's Alpha values of all four sub-scales were greater than .700 (Pallant, 2005). 
Table 1. Reliability of the questionnaire

\begin{tabular}{lll}
\hline Sub-scales & Cronbach' Alpha & Items \\
\hline Importance of learner autonomy & .784 & 4 \\
Responsibilities of learner autonomy & .721 & 10 \\
Abilities of learner autonomy & .803 & 7 \\
Behaviors of learner autonomy & .715 & 11 \\
Total & .732 & 32 \\
\hline
\end{tabular}

Purposely, the researcher decided to employ a semi-structured interview as a subordinate tool, which could make it possible to investigate the target phenomenon in greater depth and breadth (O'Hanlon, 2003). In harmony with the questionnaire, the semi-structured interview included nine questions in total, which mentioned the English-majored sophomores' self-perception of the importance of learner autonomy, their autonomous responsibilities, abilities, and inside and outside behaviors, respectively.

\subsection{Data Collection and Analysis}

On the chosen dates, the questionnaire copies which had been translated into Vietnamese beforehand were delivered to 80 participants. On the receipt of questionnaires from the respondents, the researcher found that all 80 copies $(100 \%)$ were valid and accepted. Finally, the researcher employed Statistical Package for the Social Sciences (SPSS) version 20.0 to analyze the descriptive statistics of the collected questionnaires in terms of percentage (P), mean (M) and standard deviation (S.D.). Besides, the English-majored sophomores' responses to the questionnaire items were inspected according to the rating intervals: 1.00-1.80: strongly disagree; 1.81-2.60: disagree; 2.61-3.40: moderately agree; 3.41-4.20: highly agree; 4.21-5.00: strongly agree (Pallant, 2005).

After finishing the questionnaire treatment, the researcher invited eight members from the target sample (10\%) to participate in the interviews. The interviewees were labeled from S1 to S8. The interviews were conducted in the Vietnamese language using a set of semi-structured questions to ask and a tape recorder to record the interviewees' answers. Afterwards, the researcher transcribed-"converting audio-tape recordings into text data" (Creswell, 2012, p. 239), and translated the interview transcripts for analysis intention. Finally, the researcher organized the coded data into the pre-determined themes, including the participants' self-perception of learner autonomy importance, autonomous responsibilities, abilities, and inside and outside behaviors.

\section{Results}

\subsection{The Students' Overall Self-Perception of the Importance of Learner Autonomy}

As noted earlier, learner autonomy is believed to be necessary for the language learners to develop and for the language teachers to foster in their classrooms (Alonazi, 2017) due to its benefits on learning achievements. Therefore, this part predominantly attempts to seek how the English-majored sophomores at Hung Vuong University, Vietnam perceived the importance of learner autonomy in their language learning.

Table 2. The students' overall self-perception of the importance of learner autonomy

\begin{tabular}{|c|c|c|c|c|c|c|c|c|}
\hline Item & $\begin{array}{l}\text { Learner Autonomy Importance } \\
\mathrm{N}=80(100 \%)\end{array}$ & 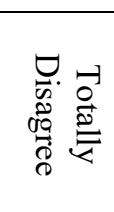 & 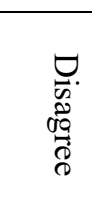 & 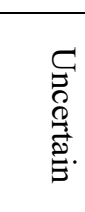 & 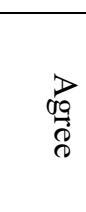 & 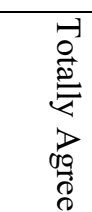 & M & S.D. \\
\hline $\mathrm{I} 1$ & Learner autonomy is important to me. & 6.3 & 3.8 & 17.5 & 51.2 & 21.3 & 3.78 & 1.03 \\
\hline I2 & $\begin{array}{l}\text { Learner autonomy helps me accomplish P (\%) } \\
\text { better learning outcomes. }\end{array}$ & 2.5 & 6.3 & 15.0 & 45.0 & 31.3 & 3.96 & .97 \\
\hline I3 & $\begin{array}{l}\text { Learner autonomy makes me learn P (\%) } \\
\text { English purposely and strategically. }\end{array}$ & 0.0 & 0.0 & 6.3 & 48.8 & 45.0 & 4.39 & .61 \\
\hline I4 & $\begin{array}{l}\text { I need to develop my learner autonomy in } \mathrm{P}(\%) \\
\text { learning English. }\end{array}$ & 10.0 & 13.8 & 18.8 & 43.8 & 13.8 & 3.38 & 1.18 \\
\hline
\end{tabular}


Table 2 shows that nearly three quarters of the participants reckoned that learner autonomy was important to them (Item I1, $21.3 \%$ totally agree, $51.2 \%$ agree, $\mathrm{M}=3.78$, S.D. $=1.03$ ). In specific, the majority of the respondents tallied that learner autonomy helped them accomplish better learning outcomes (Item I2, 31.3\% totally agree, $45.0 \%$ agree, $\mathrm{M}=3.96$, S.D. $=.97$ ). By the highest mean score (Item I3, M = 4.39, S.D. $=.61$ ), almost all the participants (45.0\% totally agree, $48.8 \%$ agree) united that learner autonomy helped them learn English purposely and strategically. Positively, more than a half of the sample disclosed that they needed to develop their learner autonomy in learning English (Item I4, 13.8\% totally agree, 43.8\% agree, M = 3.38, S.D. $=$ 1.18). In general, the large number of the English-majored sophomores at Hung Vuong University, Vietnam showed their positive self-perception (e.g. cognitive and behavioral attitudes in this case) of learner autonomy and its importance.

Coupled with the questionnaire results, the interview results also display participants' strong agreement on the importance of learner autonomy. As for the first interview question-Do you think learner autonomy is important to your language learning? Why (not)?, all the eight interviewees avowed "Yes", "Of course" or "Absolutely agree"; then, they divulged some benefits. The first benefit for the importance was that learner autonomy could make them learn English purposely and systematically through use of autonomous planning, regulating and evaluating strategies (e.g. S1, S2, S4, S5, S7 and S8). The importance of learner autonomy was also perceived as a learning way to help learners attain the learning goals successfully (e.g. S2, S3, S6 and S8). For example, S1 stated that

I absolutely agree with the importance of learner autonomy in my language learning process. It facilitates me to learn English intentionally and strategically. In fact, I must manipulate different learning strategies for my autonomous learning like self-planning, self-controlling and self-evaluating ones. (S1-Q1)

\subsection{The Students' Self-Perception of Their Autonomous Responsibilities}

When learning English autonomously, it requires the language learners to recognize their responsibilities so that learning outcomes can be effectively obtained and ideal autonomous learners can be successfully formed. Littlewood (1996) states that to become ideal autonomous learners, the language learners need to undertake a multiple of responsibilities such as deciding on learning objectives, selecting learning methods, and evaluating process, etc. In addition, to increase higher level of learner autonomy, it is necessary to develop a sense of responsibility among learners themselves (Scharle \& Szabó, 2000). Thereby, this part is conducive to making an exploration of how the participants perceived their responsibilities in their autonomous language learning.

Table 3. The students' self-perception of their autonomous responsibilities

\begin{tabular}{|c|c|c|c|c|c|c|c|c|c|}
\hline Item & $\begin{array}{l}\text { Autonomous Responsibilities } \\
\mathrm{N}=80(100 \%)\end{array}$ & & 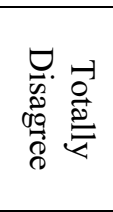 & 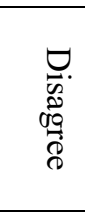 & 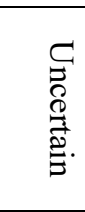 & 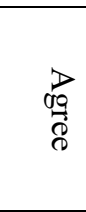 & 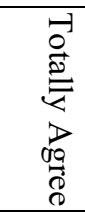 & M & S.D. \\
\hline \multicolumn{10}{|c|}{ When learning English at university, I must take responsibility to } \\
\hline $\mathrm{R} 1$ & identify learning objectives of courses & $\mathrm{P}(\%)$ & 0.0 & 0.0 & 12.5 & 31.3 & 56.3 & 4.44 & .71 \\
\hline $\mathrm{R} 2$ & choose learning materials & $\mathrm{P}(\%)$ & 10.0 & 16.3 & 25.0 & 28.7 & 20.0 & 3.33 & 1.25 \\
\hline $\mathrm{R} 3$ & select learning methods and strategies & $\mathrm{P}(\%)$ & 3.8 & 10.0 & 5.0 & 56.3 & 25.0 & 3.89 & 1.02 \\
\hline $\mathrm{R} 4$ & choose learning activities and tasks & $\mathrm{P}(\%)$ & 6.3 & 6.3 & 15.0 & 31.3 & 41.3 & 3.95 & 1.18 \\
\hline R5 & be hard-working & $\mathrm{P}(\%)$ & 0.0 & 2.5 & 6.3 & 10.0 & 81.3 & 4.70 & .70 \\
\hline R6 & $\begin{array}{l}\text { identify weaknesses and strengths of my } \\
\text { English skills and knowledge }\end{array}$ & $\mathrm{P}(\%)$ & 10.0 & 2.5 & 13.8 & 43.8 & 30.0 & 3.81 & 1.19 \\
\hline R7 & evaluate my own learning progress & $\mathrm{P}(\%)$ & 7.5 & 7.5 & 22.5 & 26.3 & 36.3 & 3.76 & 1.24 \\
\hline
\end{tabular}

As displayed in Table 3, the majority of the English-majored sophomores at Hung Vuong University, Vietnam positively perceived responsibilities in their autonomous language learning. By the highest mean score (Item R5, $\mathrm{M}=4.70$, S.D. $=.70,81.3 \%$ totally agree, $10.0 \%$ agree), nearly all of the participants realized their responsibility to be hard-working while learning English. By the second highest mean score (Item R1, M = 4.44, S.D. = .71), more than four-fifths of the sample admitted their responsibility to identify learning goals/ objectives of the 
given courses while learning English (56.3\% totally agree, 31.3\% agree).

In addition, four other autonomous learning responsibilities were also considered by a big proportion of the target sample. Specifically, beyond four-fifths of the sample (25.0\% totally agree; $56.3 \%$ agree) realized their autonomous responsibility to select learning methods and strategies (Item R3, M = 3.89, S.D. $=1.02$ ). Furthermore, the responsibility to choose learning activities and tasks in autonomous language learning was concurred by approximately three quarters of the response community (Item R4, 41.3\% totally agree, 31.3\% agree, $\mathrm{M}=3.95$, S.D. $=1.18$ ). Moreover, around three quarters of the target sample also recognized the autonomous responsibility to identify weaknesses and strengths of my English skills and knowledge (Item R6, $30.0 \%$ totally agree, $43.8 \%$ agree, $\mathrm{M}=3.81$, S.D. $=1.19)$. Besides, with Item R7 $(\mathrm{M}=3.76$, S.D. $=1.24)$, the autonomous responsibility to evaluate their own learning progress was also discerned by about two-thirds of the response community ( $36.3 \%$ totally agree, $26.3 \%$ agree)

However, only roughly a half of the total participants (48.7\%) ascertained choosing learning materials as one autonomous responsibility taken by them. Indeed, among the entire sample, only $20.0 \%$ and $28.7 \%$ showed their total agreement and agreement on this statement, respectively, which contributed to the medium mean score of Item R2 (M=3.33, S.D. $=1.25)$.

Qualitatively, the interview results also exhibited the quite similar tendency with the questionnaire results above. In specific, when the researcher asked the second interview question-Which responsibilities do you perceive that you must take during your English learning?, all the interviewees mentioned the autonomous responsibility to identify learning objectives of courses, followed by the responsibility to be hard-working for language learning which was chosen by seven interviewees excluding S4. In addition, five out of eight interviewees (e.g. S1, S3, S4, S6 and S7) reckoned that they were responsible for choosing learning strategies and learning activities. Besides, there were four interviewed participants, including S2, S5, S6 and S8, who specified the necessary responsibility to self-evaluate their learning progress over the time. Finally, only two interviewees, i.e. S3 and S8 assumed that they were responsible for selecting learning materials. The third interview question-Do you think selecting learning materials is your responsibility? Why (not)?-was added to seek the explanation on the least choice. The most common answer to this question was that selection of learning materials is extremely tremendous to the learners as there exist too many learning materials to opt, and the teachers should undertake this responsibility or guide them much to enact this action. For example, S5 and S7 stated that

I think that selecting learning materials or content should be granted for the teachers as it is actually challenging to my ability. In fact, there were a lot of things to pick up. (S5-Q3)

[....] At least, the teachers need to guide us to choose the suitable learning materials by some suggestions. (S7-Q3)

\subsection{The Students' Self-Perception of Their Autonomous Abilities}

According to Little (2001), autonomous learners are believed to have abilities to self-plan, self-manage, self-monitor, and self-assess their learning. Besides, as Omaggio (1978) states, autonomous learners have insights and capacities into their learning strategies and preferential activities. Hence, this part is dedicated to probing to what extent the English-majored sophomores built up their autonomous abilities in their language learning over the time of two years.

Table 4. The students' self-perception of their autonomous abilities

\begin{tabular}{|c|c|c|c|c|c|c|c|c|c|}
\hline Item & \multicolumn{2}{|l|}{$\begin{array}{l}\text { Autonomous Abilities } \\
\mathrm{N}=80(100 \%)\end{array}$} & 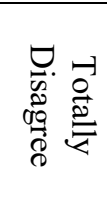 & 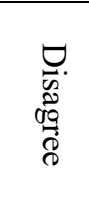 & 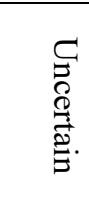 & 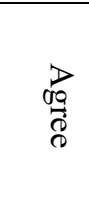 & 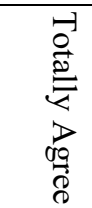 & $\mathrm{M}$ & S.D. \\
\hline \multicolumn{10}{|c|}{ After nearly two-year experience of English learning at university, I can } \\
\hline$\overline{\mathrm{A} 1}$ & identify my objectives inside class & $\mathrm{P}(\%)$ & 3.8 & 5.0 & 13.8 & 31.3 & 46.3 & 4.11 & 1.07 \\
\hline $\mathrm{A} 2$ & identify my objectives outside class & $\mathrm{P}(\%)$ & 7.5 & 10.0 & 18.8 & 25.0 & 38.8 & 3.78 & 1.27 \\
\hline A3 & select learning materials inside class & $\mathrm{P}(\%)$ & 1.3 & 3.8 & 7.5 & 26.3 & 61.3 & 4.43 & .88 \\
\hline A4 & select learning materials outside class & $\mathrm{P}(\%)$ & 13.8 & 10.0 & 38.8 & 28.7 & 8.8 & 3.09 & 1.14 \\
\hline A5 & select learning methods and strategies & $\mathrm{P}(\%)$ & 3.8 & 8.8 & 6.3 & 25.0 & 56.3 & 4.21 & 1.13 \\
\hline
\end{tabular}


inside class

A6

A7

A8

A9

A10

select learning methods and strategies

outside class

P (\%) 13.8

17.5

31.3

26.3

11.3

3.04

1.21

select learning activities and tasks inside

class

P (\%) 8.8

6.3

13.8

26.3

45.0

3.93

1.28

select learning activities and tasks outside class

$\mathrm{P}(\%) 7.5$

13.8

26.3

40.0

$12.5 \quad 3.36$

1.11

identify weaknesses and strengths of my P (\%)

English skills and knowledge

5.0

evaluate my learning progress

P (\%) 7.5

10.0

16.3

$27.5 \quad 45.0 \quad 4.00$

1.18

As Table 4 illustrates, the majority of the participants confessed that they possessed autonomous ability to identify their learning objectives inside class (Item A1, 46.3\% totally agree and $31.3 \%$ agree) and outside class (Item A2, 38.8\% totally agree and $25.0 \%$ agree). By comparison of mean scores, this autonomous ability inside class seemed to outperform that outside class, with $\mathrm{M}=4.11$ (S.D. $=1.07)$ and $\mathrm{M}=3.78$ (S.D. $=1.27$ ), respectively.

In addition, while the majority of the participants believed in their ability to select learning materials inside class (Item A3, 61.3\% totally agree and $26.3 \%$ agree), the minority of the entire sample perceived this ability outside class (Item A4, $8.8 \%$ totally agree and $28.7 \%$ agree). This difference was also evidently observed by the compassion of mean indexes, in which the mean value of Item A3 was at a high level $(\mathrm{M}=4.43$, S.D. $=.88)$ and that of Item A4 was at a moderate high level $(\mathrm{M}=3.09$, S.D. $=1.14)$.

Besides, while roughly four-fifths of the response community $(81.3 \%)$ admitted their autonomous ability to select learning methods and strategies inside class (Item A5, 56.3\% totally agree, $25.0 \%$ agree, M $=4.21$, S.D. $=$ 1.13), only one-third of the whole sample (37.6\%) acquiesced this ability outside class (Item A6, $11.3 \%$ totally agree, $26.3 \%$ agree, $\mathrm{M}=3.04$, S.D. $=1.21$ ).

Furthermore, the ability to select learning activities and tasks inside class was deemed to be superior to that outside class. Numerically, the former ability was perceived by nearly three quarters of the total respondents (Item A7, $45.0 \%$ totally agree and $26.3 \%$ agree) while the latter ability was divulged by more than a half of the total informants (Item 8, 12.5\% totally agree and $40.0 \%$ agree). More statistically, the mean value of Item A7 was much higher than that of Item $\mathrm{A} 8$, with $\mathrm{M}=3.93$ (S.D. $=1.28$ ) and $\mathrm{M}=3.36$ (S.D. $=1.11$ ), respectively.

Positively, approximately three quarters of the participants ( $72.5 \%$ and $75.1 \%$, respectively) acknowledged their autonomous ability to identify weaknesses and strengths of their English skills and knowledge (Item A9, 45.0\% totally agree, $27.5 \%$ agree, $\mathrm{M}=4.00$, S.D. $=1.18$ ) and autonomous ability to evaluate their learning progress (Item A10, $53.8 \%$ totally agree, $21.3 \%$ agree, $\mathrm{M}=4.04$, S.D. $=1.31$ ).

Coupled with the questionnaire results, the qualitative results emanated from the interviews also showed the similar fashion. Specifically, when the researcher asked the fourth interview question-What are your autonomous abilities in their language learning?, six interviewees excluding S2 and S5 listed inside autonomous abilities only such as defining learning objectives, opting learning materials, or selecting learning strategies and tasks (75.0\%). Meanwhile, S2 and S5 considered their autonomous abilities both inside and outside class (25.0\%). All of them revealed their abilities to assess language skills and knowledge and evaluate learning progress inside class (100\%). To illuminate this striking finding, the fifth interview question was supplemented, i.e. Why do you perform autonomous abilities inside class better than outside class? Some reasons were ultimately sought regarding the presence of the language teachers in the classroom, the crystal clear prescription of the syllabi, and the teachers' useful instructions and suggestions. Below are some extracts as evidence:

[...] That is because my teachers are present in the classrooms who contribute much to building my autonomous learning abilities. (S1-Q5)

Simply, objectives, materials, activities and strategies inside class are meticulously involved in the syllabi, and in the teachers' instructions and suggestions. (S8-Q5)

\subsection{The Students' Self-Perception of Their Autonomous Inside and Outside Behaviors}

According to Sinclair (2000), autonomous leaning can take place both inside and outside the class. Besides, it is notoriously assumed that autonomous learning behaviors can be reflected on the interactions between language 
learners with their teachers, with their classmates and with themselves. Hence, this part is designed to make an investigation of how the English-majored sophomores signified their autonomous behaviors both inside and outside class.

Table 5. The students' self-perception of their autonomous inside behaviors

\begin{tabular}{|c|c|c|c|c|c|c|c|c|}
\hline Item & $\begin{array}{l}\text { Autonomous Inside Behaviors } \\
\mathrm{N}=80(100 \%)\end{array}$ & 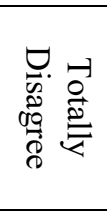 & 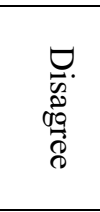 & $\begin{array}{l}\stackrel{c}{\overrightarrow{0}} \\
\stackrel{0}{9} \\
\overrightarrow{\vec{E}} .\end{array}$ & 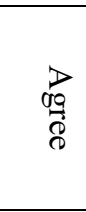 & 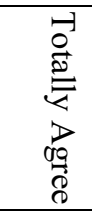 & M & S.D. \\
\hline \multicolumn{9}{|c|}{ After nearly two-year experience of English learning at university, I have } \\
\hline IB1 & take notes of the lessons & 6.3 & 5.0 & 13.8 & 31.3 & 43.8 & 4.01 & 1.16 \\
\hline IB2 & $\begin{array}{l}\text { work with my classmates (e.g. ask for } \mathrm{P}(\%) \\
\text { clarification, exchange feedback) }\end{array}$ & 7.5 & 10.0 & 18.8 & 25.0 & 38.8 & 3.78 & 1.27 \\
\hline IB3 & $\begin{array}{l}\text { ask help from my teachers when } \mathrm{P}(\%) \\
\text { necessary }\end{array}$ & 18.8 & 15.0 & 33.8 & 26.3 & 6.3 & 2.86 & 1.19 \\
\hline
\end{tabular}

As shown in Table 5, a large number of the English-majored sophomores had taken notes of the lessons after their nearly two-year experience of English learning at university. Numerically, right three quarters of the whole sample revealed this autonomous behavior (Item IB1, 43.8\% totally agree, $31.3 \%$ agree, $\mathrm{M}=4.01$, S.D. $=1.16$ ). Likewise, around two-thirds of the response community $(63.8 \%)$ admitted that they had worked actively with their classmates such as asking for clarification or exchanging feedback after their nearly two-year experience of English learning at Hung Vuong University, Vietnam (Item IB2, 38.8\% totally agree, $25.0 \%$ agree, $\mathrm{M}=3.78$, S.D. $=1.27)$. Nevertheless, only one-third of the total sample $(32.6 \%)$ had asked help from their teachers when necessary after their nearly two-year experience of English learning at university (Item IB3, 6.3\% totally agree and $26.3 \%$ agree $)$. Accordingly, the mean score of this item was quite low $(\mathrm{M}=2.86$, S.D. $=1.19)$. Generally speaking, it seemed that the English sophomores favored working with themselves or with their classmates in lieu of with their teachers.

The interview results of the sixth question-What are your autonomous behaviors inside class after nearly two-year experience of English learning at university?-also displayed the similar trend with the questionnaire results. As avowed by all the eight interviewees, the university learners only listened to the lectures and took notes of key information in the classroom. In case that they did not understand something, they usually asked other learners next to them. The seventh question-Why do not you ask teachers for help when necessary?-was added to the interview to find out the explanation on the learners' ignorance of interacting with their teachers in the classroom. As a result of this question, the English-majored sophomores did not lean on their teachers as they were shy or reticent. For example, S3 stated

When I do not understand some places in the lectures, I usually skip or just ask my classmates around me. I almost never had my teachers explain because I feel afraid and shy. (S3-Q7)

Table 6. The students' self-perception of their autonomous outside behaviors

\begin{tabular}{|c|c|c|c|c|c|c|c|c|}
\hline Item & $\begin{array}{l}\text { Autonomous Outside Behaviors } \\
\mathrm{N}=80(100 \%)\end{array}$ & 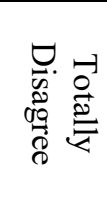 & 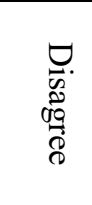 & 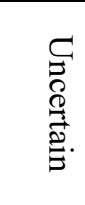 & 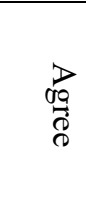 & 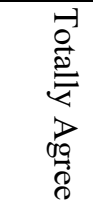 & $\mathrm{M}$ & S.D. \\
\hline \multicolumn{9}{|c|}{ After nearly two-year experience of English learning at university, I have __outside classroom. } \\
\hline OB1 & $\begin{array}{l}\text { done extra activities and tasks which are } \mathrm{P}(\%) \\
\text { not demanded by my teachers }\end{array}$ & 18.8 & 21.3 & 26.3 & 15.0 & 18.8 & 2.94 & 1.37 \\
\hline OB2 & $\begin{array}{l}\text { listed strengths and weaknesses of my } \mathrm{P}(\%) \\
\text { English skills and knowledge }\end{array}$ & 7.5 & 15.0 & 23.8 & 42.5 & 11.3 & 3.35 & 1.10 \\
\hline
\end{tabular}




\begin{tabular}{|c|c|c|c|c|c|c|c|c|c|}
\hline OB3 & $\begin{array}{l}\text { self-practiced English listening skills via } \\
\text { the Internet or audio programs }\end{array}$ & $\mathrm{P}(\%)$ & 8.8 & 16.3 & 22.5 & 31.2 & 21.3 & 3.40 & 1.24 \\
\hline OB4 & $\begin{array}{l}\text { self-practiced English speaking skills with } \\
\text { my friends }\end{array}$ & $\mathrm{P}(\%)$ & 6.3 & 15.0 & 17.5 & 30.0 & 31.2 & 3.65 & 1.24 \\
\hline OB5 & $\begin{array}{l}\text { self-practiced English reading skills via } \\
\text { newspapers, magazines and others }\end{array}$ & $\mathrm{P}(\%)$ & 15.0 & 15.0 & 27.5 & 32.5 & 10.0 & 3.08 & 1.22 \\
\hline OB6 & $\begin{array}{l}\text { self-practiced English writing skills via } \\
\text { writing tasks on the Internet }\end{array}$ & $\mathrm{P}(\%)$ & 17.5 & 11.3 & 36.3 & 18.8 & 16.3 & 3.05 & 1.30 \\
\hline OB7 & sought and done grammar exercises & $\mathrm{P}(\%)$ & 18.8 & 23.8 & 23.8 & 18.8 & 15.0 & 2.88 & 1.34 \\
\hline OB8 & $\begin{array}{l}\text { sought vocabulary resources, learned } \\
\text { vocabulary forms and meanings }\end{array}$ & P (\%) & 12.5 & 10.0 & 18.8 & 42.5 & 16.3 & 3.40 & 1.24 \\
\hline
\end{tabular}

As Table 6 depicts, only about one-third of the total respondents $(33.8 \%)$ had done extra activities and tasks which were not demanded by their teachers after their nearly two-year experience of English learning at Hung Vuong University (Item OB1, M = 2.94, S.D. $=1.37,18.8 \%$ totally agree, $15.0 \%$ agree). Interestingly, more than a half of the response community (53.8\%) had listed strengths and weaknesses of my English skills and knowledge out of the classroom after this period of time (Item OB2, $11.3 \%$ totally agree, $42.5 \%$ agree, $\mathrm{M}=3.35$, S.D. $=1.10)$.

Obviously, many participants had frequently self-practiced English speaking skills with their friends (Item OB4, $31.2 \%$ totally agree, $30.0 \%$ agree, $\mathrm{M}=3.65$, S.D. $=1.24$ ) and self-practiced English listening skills through the Internet or audio programs (Item OB3, $21.3 \%$ totally agree, $31.2 \%$ agree, $\mathrm{M}=3.40$, S.D. $=1.24$ ) out of the class after their nearly two-year learning experience at university. Meanwhile, outside the class, only some learners had frequently self-practiced English reading skills through newspapers, magazines and others (Item OB5, $10.0 \%$ totally agree, $32.2 \%$ agree, $\mathrm{M}=3.08$, S.D. $=1.22$ ) and self-practiced English writing skills through writing tasks on the Internet (Item OB6, $16.3 \%$ totally agree, $18.8 \%$ agree, $\mathrm{M}=3.05$, S.D. $=1.30$ ).

On one hand, approximately sixty percent of the total participants $(58.8 \%)$ had focused on seeking vocabulary resources and learning vocabulary forms and meanings by themselves outside the class after their nearly two-year experience of English learning at Hung Vuong University, Vietnam (Item OB8, 16.3\% totally agree, $42.5 \%$ agree, $\mathrm{M}=3.40$, S.D. $=1.24)$. On the other hand, only one-third of the response community $(33.8 \%)$ had concentrated on building up their grammar knowledge via exercises or tasks after two-year learning experience at university (Item OB7, $15.0 \%$ totally agree, $18.8 \%$ agree, $\mathrm{M}=2.88$, S.D. $=1.34$ ).

Congruently, the qualitative results emerged from the interview unraveled the similar tendency with the questionnaire results. When the eighth interview question-What are your autonomous outside behaviors after nearly two-year experience of English learning at university?-was generated, five out of the eight interviewees (e.g. S1, S2, S4, S5 and S7) reckoned that they had thought of and made a list of their English weaknesses and strengths at home. Besides, some English knowledge and skills had been also paid attention to some extent in autonomous out-of-class learning such as listening (5/8 interviewees), speaking ( $7 / 8$ interviewees), reading (3/8 interviewees), writing ( $2 / 8$ interviewees), grammar ( $3 / 8$ interviewees) and vocabulary (5/8 interviewees). The ninth interview question-Why do not you self-practice reading, writing skills and grammar outside the class?-was spontaneously raised to spotlight the reasons why these skills and grammar were not the interviewed learners' favorable outside behaviors. In common, reading and writing skills and grammar were boring, challenging and even unimportant as the interview informants unveiled. Below are some evident examples:

At home, I usually think of how my English language has strengths and weaknesses and then I make a list of them which helps me much to improve and modify. (S5-Q8)

[...] That is because reading and writing skills are tedious and burdensome, even they are not as important as speaking and listening skills. Honestly, I prefer communicative skills such as listening or speaking. (S3-Q9)

I do not often concentrate on self-practicing grammar since I think that it is not really important. Conversely, I consider that have good lexical knowledge is necessary. (S8-Q9)

\section{Discussion}

First of all, it can be noted that the majority of the English-majored sophomores generally understood the importance of learner autonomy in their language learning which helped them achieve better learning outcomes 
and made them learn English more strategically and purposely. Consistently, these results presented above were in the same line with some presuppositions in the relevant literature. In principle, learner autonomy can help language learners self-plan and self-control their learning process thanks to manipulating different learning strategies (Harmer, 2007). In addition, as a result of learner autonomy, learners become more active and independent in self-evaluating their learning progress (Crabbe, 1999). Likewise, promoting learner autonomy is beneficial to make learners learn English more purposely and strategically as it encourages them to increase their self-awareness about what their goals are in the classroom (Thanasoulas, 2000). To recap, the majority of the English-majored sophomores at Hung Vuong University, Vietnam ultimately acknowledged the importance of learner autonomy in their language acquisition due to these benefits.

Secondly, concerning the construct of responsibilities, the large number of the participants positively recognized their autonomous responsibilities in a variety of learning aspects such as making efforts, identifying learning objectives, choosing learning strategies and activities, evaluating their language and learning progress. It is a favorable signal when a large number of the English-majored sophomores thought of studying diligently as their utmost vital responsibility. Indeed, when an intensive degree of learning takes place, the learners' exposure to language knowledge and skills can be expanded. The learners have to keep in mind the idea that their learning progress is based on their own efforts (Scharle \& Szabó, 2000). In addition, the majority of the participants realized their responsibilities to identify learning goals, select learning strategies/ methods, choose learning tasks/ activities, and evaluate their learning progress. Literally, learner autonomy is to take responsibility for one's own objectives, content, progress, method and techniques of learning and the evaluation of the learning process (Holec, 1981; Macaro, 1997). It is inferred that the English-majored sophomores should be responsible for different autonomous learning behaviors if they want to develop their learner autonomy degree. However, many learners seemed to ignore their responsibility to choose learning materials or contents. They considered that making choice of learning contents and materials should belong to their teachers' responsibilities and roles. As noted earlier by Macaro (1997) and Holec (1981), autonomous learners have to take their responsibility to define contents (e.g. learning materials) when they participate in any learning course. By anyway, the teachers should undertake their facilitating roles to help their language learners to do this action effectively since the fact that there is an overwhelming quantity of different learning materials and resources to study.

Thirdly, with regards to autonomous learning abilities, there was a plight that many learners' autonomous abilities inside class outperformed those outside class. Despite the fact that most of the surveyed learners positively perceived their autonomous responsibilities, many learners' autonomous learning abilities were actually limited to some extent, especially their abilities outside classroom. In academia, Littlewood (1996) believes that language learners inherently possess a set of potential autonomous abilities to shape their own learning both inside and outside classroom. Nevertheless, it is assumed that teachers should play a critical role in provoking these autonomous learning abilities, helping learners to develop confidence, motivation, abilities (e.g. knowledge and skills) so that they can learn independently, and become autonomous agents in any learning environment (Littlewood, 1996). To elaborate, the results of this study unveiled that the gap between the learners' gained autonomous inside and outside abilities relied on the situation where the teachers were present inside classroom, and all objectives, strategies, activities and materials were all-inclusive in the given syllabi. Once again, it is reckoned that the language learners' autonomous abilities outside class may be accumulated within the teachers' support, guide and tutor where necessary. Indeed, "learner autonomy is an achievement, attained interrelationally between the learner and the teacher" (Ganza, 2008, p. 65). On the contrary, without the teacher's support and guide, the autonomous learning process may get low efficiency or even fall into disorder (Duong, 2015). Succinctly, to build up the learners' holistic autonomous abilities, it is imperative for language teachers at Hung Vuong University, Vietnam to undertake various facilitating roles such as counselor, tutor, manager and active participants (Nguyen, 2014) in specific learning milieus like inside and outside class.

Fourthly, with reference to autonomous inside learning behaviors, the big portion of the surveyed learners would rather interact with their classmates (e.g. asking for clarification) or with themselves (e.g. note-taking) than contact with their teachers (e.g. asking help). This unexpected dilemma derived from the fact that they felt reticent or reserved. As noted earlier, the language teachers' task is to make learners enlarge their confidence and motivation to learn independently and become autonomous individuals in any learning circumstances (Littlewood, 1996; Dörnyei, 2001). As per Dörnyei and Csizer (1998), one of motivational strategies for learners' autonomous learning is that teachers should make a good rapport with their learners in class, encourage them to use language confidently, but over-emphasize correction. In general, the teachers need to make the class environment more interesting and comfortable, stimulating the students to become more confident learners.

Finally, considering the construct of autonomous outside behaviors, it seemed that many learners did not 
complete selective assignments, self-practice reading, writing and grammar because they perceived that they were unimportant and challenging. On the contrary, they would rather spend time self-training listening, speaking and vocabulary. Interestingly, more than a half of the learners thought of and made a list of their language strengths and weaknesses. According to Benson (2011), out-of-class autonomous learning makes a significant contribution to higher levels of language proficiency. Yet, only some learners really focused on optional assignments or tasks outside the classroom. Literally, the language learners should keep in their mind that practice makes perfect. Put another way, just inside-the-classroom activities are not enough for language to get language skills and knowledge (Dang, 2012; Duong, 2015), but the language learners need to energetically engage in the process of building their own knowledge and skills outside classroom (Hsieh \& Hsieh, 2019). Positively, many sophomores somehow paid attention to their existing strengths and weaknesses of their English language. This was viewed as a favorable result because one of the most salient characteristics of autonomous learners is their possession of metacognitive strategies (e.g. evaluating strategies) enabling them to self-monitor and self-regulate their learning process (Wenden, 1991). Indeed, when English language is personally assessed, the language learners can define what and how to reduce their own current weaknesses. Additionally, while many English-majored sophomores experienced their autonomous learning behaviors on listening, speaking and vocabulary, they neglected to self-practice reading, writing and grammar out of the class. By reason, the latter language skills and knowledge were supposed to lack their attractiveness and practicality. The learners of this study should remember that one person's language proficiency level is holistically assessed on all four skills (e.g. listening, speaking, reading and writing) and on language knowledge (e.g. vocabulary and grammar). Therefore, the English-majored sophomores should reconsider this imbalance in their autonomous outside behaviors. Additionally, the teachers can suggest interesting and communicative resources of reading, writing and grammar to their learners.

\section{Reference}

Al-Asmari, A. R. (2013). Practices and prospects of learner autonomy: Teachers' perceptions. English Language Teaching Journal, 6(3), 1-10. https://doi.org/10.5539/elt.v6n3p1.

Alonazi, S.M. (2017). The Role of teachers in promoting learner autonomy in secondary schools in Saudi Arabia. English Language Teaching, 10(7), 183-202. https://doi.org/10.5539/elt.v10n7p183.

Benson, P. (2007). Autonomy in language teaching and learning. Language Teaching, 40(1), 21-40. https://doi.org/10.1017/S0261444806003958.

Benson, P. (2011). Teaching and researching autonomy (2nd ed.). London: Pearson Education.

Borg, S., \& Al-Busaidi, S. (2012). Teachers' beliefs and practices regarding learner autonomy. ELT Journal, 66(3), 283-292. https://doi.org/10.1093/elt/ccr065

Brown, H. D. (2007). Teaching by principles: An interactive approach to language pedagogy (3rd ed.). New York: Pearson Longman.

Camilleri, G. (Ed.). (1999). Learner autonomy: The teachers' views. Strasbourg: Council of Europe Publishing.

Crabbe, D. (1999). Learner autonomy and the language teacher. In C. Ward, \& W. Renandya (Eds.), Language Teaching: New Insights for the Language Teacher (pp. 242-258). SEAMEO Regional Language Centre.

Creswell, J. W. (2012). Educational research: Planning, conducting, and evaluating quantitative (4th ed.). Boston, MA: Pearson Education.

Dang, T. T. (2012). Learner autonomy perception and performance: A study on Vietnamese students in online and offline learning environments (Unpublished doctoral dissertation). Australia: La Trobe University.

Dörnyei, Z. (2001). Motivational strategies in the language classroom. Cambridge: Cambridge University Press. https://doi.org/10.1017/CBO9780511667343.

Dörnyei, Z. (2010). Questionnaires in second language research: construction, administration, and processing (2nd ed.). London, Routledge. https://doi.org/10.4324/9780203864739.

Dörnyei, Z., \& Csizér, K. (1998). Ten commandments for motivating language learners results of an empirical study. Language Teaching Research, 2(3), 203-229. https://doi.org/10.1177/136216889800200303.

Duong, M. T. (2015). A portfolio-based learner autonomy development model in an EFL writing course (Unpublished doctoral dissertation). Thailand: Suranaree University of Technology.

Ganza, W. L. (2008). Learner autonomy-Teacher autonomy. In T. Lamb \& H. Reinders (Eds.), Learner and teacher autonomy: Concepts, realities and responses (pp. 63-79). Amsterdam/Philadelphia: John Benjamin. 
https://doi.org/10.1075/aals.1.08la.

Harmer, J. (2007). The Practice of English Language Teaching. Harlow: Longman. https://doi.org/10.1093/ elt/ccn029.

Han, L. (2014). Teacher's role in developing learner autonomy: A Literature review. International Journal of English Language Teaching, 1(2), 21-27. https://doi.org/10.5430/ijelt.v1n2p21.

Hsieh, H-C., \& Hsieh, H-L. (2019). Undergraduates' out-of-class learning: Exploring EFL students' autonomous learning behaviors and their usage of resources. Education Science, 9(159), 1-15. https://doi.org/10.3390/ educsci9030159.

Holec, H. (1981). Autonomy and foreign language learning. Oxford: Pergamon Press.

Koshy, V. (2005). Action research for improving practice: A Practical Guide. London: PCP/Sage Publications.

Little, D. (2001). Learner autonomy and the challenge of tandem language learning via the Internet. In A. Chambers, \& G. Davis (Eds.), ICT and language learning: A European perspective (pp. 29-38). Amsterdam: Swets \& Zeitlinger Publishers.

Littlewood, W. (1996). "Autonomy": An anatomy and a framework. System, 24(4), 427-435. https://doi:10.1016/S0346-251X(96)00039-5.

Littlewood, W. (1999). Defining and developing autonomy in East Asian contexts. Applied Linguistics, 20(1), 71-94. https://doi.org/10.1093/applin/20.1.71.

Littlewood, W. (2000). Do Asian students really want to listen and obey? ELT Journal, 54(1), 31-36. https://doi.org/10.1093/elt/54.1.31.

Macaro, E. (1997). Target language, collaborative learning, and autonomy. Clevedon, UK: Multilingual Matters.

Nguyen, T. P. T. (2019). Teachers' beliefs in the necessity and feasibility of fostering learner autonomy in learning writing (Unpublished master's thesis). Vietnam: Ho Chi Minh City Open University.

Nguyen, T. N. (2014). Learner autonomy in language learning: Teachers' beliefs (Unpublished doctoral dissertation). Australia: Queensland University of Technology.

O'Hanlon, C. (2003). Educational inclusion as action research: An interpretive discourse. Buckingham: Open University Press.

Omaggio, A. C. (1978). Successful language learners: What do we know about them? ERIC/CLL News Bulletin, May, 2-3.

Pallant, J. (2005). SPSS survival guide: A step by step guide to data analysis using SPSS for windows. (3rd ed.). New York: Open University Press.

Riihimäki, J. (2013). Autonomous language learning in EFL classrooms in Finland: A descriptive study (Unpublished master's thesis). Finland: University of Jyväskylä.

Scharle, A., \& Szabó, A. (2000). Learner autonomy: A guide to developing learner responsibility. Cambridge: Cambridge University Press.

Sinclair, B. (2000). Learner autonomy: The next phase? In B. Sinclair, I. McGrath \& T. Lamb (Eds.), Learner autonomy, teacher autonomy: Future directions (pp. 4-14). Harlow: Longman.

Thanasoulas, D. (2000). What is Learner Autonomy and how can it be fostered? The Internet TESL Journal, $6(11)$

Trinh, Q. L. (2005). Stimulating learner autonomy in English language education: A curriculum innovation study in a Vietnamese context (Unpublished doctoral dissertation). Netherland: University of Amsterdam.

Vázquez, M. B. (2015). Pedagogy for autonomy in FLT: An exploratory analysis on its implementation through case studies. Porta Linguarum, 23, 59-74.

Voller, P. (1997). Does the teacher have a role in autonomous language learning? In P. Benson, \& P. Voller (Eds.), Autonomy \& independence in language learning (pp. 98-113). London: Longman.

Wenden, A. L. (1991). Learner strategies for learner autonomy. Hemel Hempstead, United Kingdom: Prentice Hall. 


\section{Appendix A}

\section{Questionnaire Sample}

Dear participant,

This questionnaire belongs to a study named "The English-Majored Sophomores' Self-Perception of Autonomous Language Learning”. This questionnaire is dedicated to exploring the second-year English majors' learner autonomy at Hung Vuong University, Vietnam. We highly appreciate it if you could spend your time answering following questions. Your responses will greatly contribute to the success of this paper. Your replies will be only used for survey purposes. Thank you very much for your cooperation.

Please choose the best option for each statement below by putting $(X)$ in the suitable box:

Scale: $1=$ Totally Disagree; $2=$ Disagree; $3=$ Uncertain; 4= Agree; $5=$ Totally Agree

\begin{tabular}{|c|c|c|c|c|c|c|}
\hline Item & Statements & \multicolumn{5}{|c|}{ Scale } \\
\hline \multicolumn{7}{|c|}{ Importance of learner autonomy } \\
\hline I1 & Learner autonomy is important to me. & 1 & 2 & 3 & 4 & 5 \\
\hline $\mathrm{I} 2$ & Learner autonomy helps me accomplish better learning outcomes. & 1 & 2 & 3 & 4 & 5 \\
\hline $\mathrm{I} 3$ & Learner autonomy makes me learn English purposely and strategically. & 1 & 2 & 3 & 4 & 5 \\
\hline I4 & I need to develop my learner autonomy in learning English. & 1 & 2 & 3 & 4 & 5 \\
\hline \multicolumn{7}{|c|}{$\begin{array}{l}\text { Autonomous responsibilities } \\
\text { When learning English at university, I must take responsibility to }\end{array}$} \\
\hline $\mathrm{R} 1$ & identify learning objectives of courses & 1 & 2 & 3 & 4 & 5 \\
\hline $\mathrm{R} 2$ & choose learning materials & 1 & 2 & 3 & 4 & 5 \\
\hline R3 & select learning methods and strategies & 1 & 2 & 3 & 4 & 5 \\
\hline R4 & choose learning activities and tasks & 1 & 2 & 3 & 4 & 5 \\
\hline R5 & be hard-working & 1 & 2 & 3 & 4 & 5 \\
\hline R6 & identify weaknesses and strengths of my English skills and knowledge & 1 & 2 & 3 & 4 & 5 \\
\hline R7 & evaluate my own learning progress & 1 & 2 & 3 & 4 & 5 \\
\hline
\end{tabular}

Autonomous abilities

After nearly two-year experience of English learning at university, I can

\begin{tabular}{|c|c|c|c|c|c|c|}
\hline A1 & identify my objectives inside class & 1 & 2 & 3 & 4 & 5 \\
\hline A2 & identify my objectives outside class & 1 & 2 & 3 & 4 & 5 \\
\hline A3 & select learning materials inside class & 1 & 2 & 3 & 4 & 5 \\
\hline A4 & select learning materials outside class & 1 & 2 & 3 & 4 & 5 \\
\hline A5 & select learning methods and strategies inside class & 1 & 2 & 3 & 4 & 5 \\
\hline A6 & select learning methods and strategies outside class & 1 & 2 & 3 & 4 & 5 \\
\hline A7 & select learning activities and tasks inside class & 1 & 2 & 3 & 4 & 5 \\
\hline A8 & select learning activities and tasks outside class & 1 & 2 & 3 & 4 & 5 \\
\hline A9 & identify weaknesses and strengths of my English skills and knowledge & 1 & 2 & 3 & 4 & 5 \\
\hline A10 & evaluate my learning progress & 1 & 2 & 3 & 4 & 5 \\
\hline \multicolumn{6}{|c|}{ After nearly two-year experience of English learning at university, I have } & \\
\hline IB1 & take notes of the lessons & 1 & 2 & 3 & 4 & 5 \\
\hline IB2 & work with my classmates (e.g. ask for clarification, exchange feedback) & 1 & 2 & 3 & 4 & 5 \\
\hline IB3 & ask help from my teachers when necessary & 1 & 2 & 3 & 4 & 5 \\
\hline
\end{tabular}




\begin{tabular}{|c|c|c|c|c|c|c|}
\hline \multicolumn{7}{|c|}{ Autonomous outside behaviors } \\
\hline OB1 & done extra activities and tasks which are not demanded by my teachers & 1 & 2 & 3 & 4 & 5 \\
\hline OB2 & listed strengths and weaknesses of my English skills and knowledge & 1 & 2 & 3 & 4 & 5 \\
\hline OB3 & self-practiced English listening skills via the Internet or audio programs & 1 & 2 & 3 & 4 & 5 \\
\hline OB4 & self-practiced English speaking skills with my friends & 1 & 2 & 3 & 4 & 5 \\
\hline OB5 & self-practiced English reading skills via newspapers, magazines and others & 1 & 2 & 3 & 4 & 5 \\
\hline OB6 & self-practiced English writing skills via writing tasks on the Internet & 1 & 2 & 3 & 4 & 5 \\
\hline OB7 & sought and done grammar exercises & 1 & 2 & 3 & 4 & 5 \\
\hline OB8 & sought vocabulary resources, learned vocabulary forms and meanings & 1 & 2 & 3 & 4 & 5 \\
\hline
\end{tabular}

\section{Appendix B}

\section{Interview Sample}

Q1. Do you think learner autonomy is important to your language learning? Why (not)?

Q2. Which responsibilities do you perceive that you must take during your English learning?

Q3. Do you think selecting learning materials is your responsibility? Why (not)?

Q4. What are your autonomous abilities in their language learning?

Q5. Why do you perform autonomous abilities inside class better than outside class?

Q6. What are your autonomous behaviors inside class after nearly two-year experience of English learning at university?

Q7. Why do not you ask teachers for help when necessary?

Q8. What are your autonomous outside behaviors after nearly two-year experience of English learning at university?

Q9. Why do not you self-practice reading, writing skills and grammar outside the class?

\section{Copyrights}

Copyright for this article is retained by the author(s), with first publication rights granted to the journal.

This is an open-access article distributed under the terms and conditions of the Creative Commons Attribution license (http://creativecommons.org/licenses/by/4.0/). 